Review

\title{
Impact of Marine Drugs on Animal Reproductive Processes
}

\section{Francesco Silvestre and Elisabetta Tosti *}

Animal Physiology and Evolution Laboratory, Stazione Zoologica “Anton Dohrn”, Villa Comunale, 80121-Naples, Italy

* Author to whom correspondence should be addressed; E-Mail: tosti@szn.it; Tel.: +39 081 5833288; Fax: +39081 7641355 .

Received: 7 October 2009; in revised form: 3 November 2009 / Accepted: 6 November 2009 / Published: 6 November 2009

\begin{abstract}
The discovery and description of bioactive substances from natural sources has been a research topic for the last 50 years. In this respect, marine animals have been used to extract many new compounds exerting different actions. Reproduction is a complex process whose main steps are the production and maturation of gametes, their activation, the fertilisation and the beginning of development. In the literature it has been shown that many substances extracted from marine organisms may have profound influence on the reproductive behaviour, function and reproductive strategies and survival of species. However, despite the central importance of reproduction and thus the maintenance of species, there are still few studies on how reproductive mechanisms are impacted by marine bioactive drugs. At present, studies in either marine and terrestrial animals have been particularly important in identifying what specific fine reproductive mechanisms are affected by marine-derived substances. In this review we describe the main steps of the biology of reproduction and the impact of substances from marine environment and organisms on the reproductive processes.
\end{abstract}

Keywords: marine drugs; toxins; reproduction; fertilisation; gametes

\section{Introduction}

\subsection{Biology of Reproduction}

Reproduction is the biological process by which new individual organisms are generated. In sexual reproduction the new organism is a combination of half of the genetic material of the two parents 
through the fusion of the two gametes: spermatozoon and oocyte [1]. The gametes are formed during specific processes such as oogenesis and spermatogenesis, both characterized by a unique process of cell division occurring only in gametes, called meiosis, whose goal is the production of highly specialized haploid cells for fertilisation. During gametogenesis the two gametes respectively in the ovary and the testis undergo maturation whereas gametes are activated at fertilisation. Oocyte maturation is the last phase of oogenesis during which the oocyte acquires the competence to be ovulated and fertilised. In the majority of the species, the oocyte arrests at different stages of meiotic division, in particular the block occurring in the first meiotic prophase marks the state of immature oocyte characterized by a prominent nucleus called germinal vesicle (GV). Meiosis is resumed in response to a stimulus that is different among the species and meiosis progression occurs with the germinal vesicle breakdown (GVBD). Then it progresses until a second arrest at metaphase I (MI) or II (MII) that is removed after successful fertilisation.

Oocyte maturation is usually defined as the period of progression from the first to the second meiotic arrest and involves coordinated nuclear and cytoplasmic modifications [2]. If nuclear maturation is underlied by the meiotic process, cytoplasmic maturation is a more obscure process and involves both morphological and functional alterations related to: (i) changes in the expression profile of cell cycle control proteins responsible for driving the oocyte towards developmental competencies [3-7]; (ii) relocation of mitochondria and endoplasmic reticulum [8-10]; (iii) transcriptional modifications of mRNA [11]; (iv) modification of the plasma membrane permeability [12-15]; (v) differentiation of the calcium signalling machinery [16].

The control of oocyte maturation involves a complex interplay between oocyte and the extra cellular membranes and the environment, with the participation of numerous metabolic pathways. The resumption of meiotic maturation relies on two different mechanisms that are stimulation by chemical/hormonal substances and the removal of an inhibitory signal. The former involves the production of a ligand that acts on the oocyte at the GV stage inducing the GVBD.

Meiosis arrest and resumption are modulated by numerous messengers. Many studies have provided evidence of the involvement of cyclic nucleotides in the maintenance of meiotic arrest [17]. In particular, high levels of cyclic adenosine mono-phosphate (cAMP), some analogues, cAMP-dependent protein kinase (PKA) and related substances such as GPR3, act by preventing spontaneous maturation and/or blocking GVBD in vitro or, on the contrary, may release oocyte from meiotic arrest [18,19].

Another important factor responsible for meiotic resumption is the M-phase promoting factor (MPF) showed for the first time in amphibian oocytes in the '70s, by Masui [20]. Although most of the work on MPF has been carried out with frog and starfish oocytes, accumulated evidence demonstrates that this mechanism exists in other animal models, such as mammals and invertebrates [12,16,21-23].

There is a general consensus that calcium ions play a fundamental role in the resumption of meiotic maturation $[4,16,24,25]$ in different species. The external calcium is involved in meiotic resumption in ascidian oocytes [15]. In mouse, calcium oscillations precede GVBD [26] that is delayed by removing of external calcium [27].

As showed in mammalian oocytes, meiotic maturation is a complex process that involves extensive rearrangement of microtubules and actin filaments [28]. Depending on the species, actin filaments control chromatin movement during oocyte development and regulation of organelle positioning; they 
also participate in oocyte cortex formation and in polarity establishment. The actin filaments, furthermore, play several roles in cortical granule movement, anchoring and exocytosis, and, together with myosin, are also involved in polar body emission [29].

Sperm maturation is defined as the development of the ability of spermatozoa to fertilise eggs. In this process, the sperm undergoes morphological, biochemical, and physiological modifications initially in the testis (testicular maturation) and later in the epididymis (epididymal maturation). In the former, maturation occurs at molecular levels especially during the last phase of spermatogenesis known as spermiogenesis; here, the large round haploid spermatide undergoes a dramatic morphological and molecular changes including: replacement of histones with protamines, high condensation of chromatin, formation of the acrosome, centrioles migration and tail assemblage. In the mean time, sperm acquires a functional competence, e.g., acquisition of flagellar beating providing forward propulsion and compactness of nuclear and flagellar structures.

After that, in mammals, sperm function required for fertilisation seems to be developed in the epididymis, whereas in marine animals it takes place at the moment of its spawning in the environment [1,30]. In marine organisms, spawning, i.e. the release of sperm and often eggs into the environment, is a common mechanism of reproduction [31]. The probability of successful fertilization in this mating strategy depends on many factors, including the number and the distribution of spawners [32], the timing of gamete release [33], the ways in which released gametes are dispersed [34] and finally properties of gametes themselves [35].

Fertilisation is a highly specialized process of cell to cell interaction that involves many steps such as recognition of complementary receptors on the surface of the two gametes, their binding, and the fusion of the two plasma membranes [1,36]. During this complex process each gamete activates its partner. First, the spermatozoon responds to signal originating from the oocyte and its investments by rapidly changing its behaviour, form and function. Multi-step events of sperm activation involve motility, chemotaxis, first binding, acrosome reaction, second binding and fusion [1,30,37]. All these steps are mediated by known molecules. In particular, the acrosome reaction is an essential requirement to render the sperm plasma membrane highly fusible. The acrosome is an organelle located on the tip of the sperm head and due to the contact between ligand and receptors on the two gametes membranes undergoes the exocytosis [38]. This process that is calcium-mediated allows the spermatozoon to cross the zona pellucida that surrounds the oocyte and to take contact with the oocyte plasma membrane, after that fusion of the gametes occurs [29]. Following fusion, the spermatozoon triggers the quiescent oocyte into metabolic activation inducing electrical, morphological and metabolic modifications.

Electrical changes of the oocyte plasma membrane are a crucial event of the oocyte activation [40]. First indications on the role of ion currents at fertilisation were provided in marine animals in the early ' 80 . In the echinoderm oocytes the occurrence of a depolarizing fertilisation potential was attributed to the activation of a transient voltage-dependent inward current $[41,42]$. Subsequently, it was possible to determine that the ion fluxes responsible for fertilisation potential crossed the plasma membrane as a ion current named fertilisation current [43]. Biophysical studies characterized the channels responsible for the fertilisation current as large non-specific and highly conductive ion channels $[43,44]$ and subsequently to mainly mediated by sodium currents [14]. In marine worm eggs, the fertilisation 
potential can be thought of as a sum of a $\mathrm{Na}^{+}$-dependent "sperm receptor potential" and a superimposed $\mathrm{Ca}^{2+}$-dependent action potential [45].

Resting potential changes and fertilisation currents has been recorded in many vertebrate oocytes such as amphibians [46], hamster [47], rabbit [48], mouse [49], human [50] and bovine [51]. In addition, it has been shown that electrical modifications is a mechanism for preventing polyspermy in sea urchin [52], marine worm [53], ascidian [54] and Xenopus [46] oocytes.

Morphological modifications are mainly due to the triggering of the cortical reaction [9] or to the contraction of the oocyte body due to a calcium wave that crosses it from pole to pole [55].

Finally, numerous metabolic modifications occur such as modulation of phosphoinositide pathway [5-59] with inositol trisphosphate $\left(\mathrm{IP}_{3}\right)$ formation. The latter gives rise to a fundamental event in oocyte activation [25] that is the release of intracellular calcium. This calcium signal is responsible for the exocytosis of cortical granules, resumption of meiosis and activation of development [60-65].

A calcium increase may occur in oocytes as single increase, as in amphibians [66] and sea urchins [67] or in the form of repetitive oscillations as in ascidians [68] and mammals [69-73].

In many species, fusion between sperm and the oocyte occurs at the tip of microvilli, and the actin filaments in the microvilli may participate in sperm-egg binding and fusion. As described above, the ion currents play a crucial role in the gamete activation and embryo development, so many fertilisation blockers are drugs affecting physiological modifications of cytoskeleton and/or ion currents.

In conclusion, a correct maturation and reciprocal activation of gametes are a pre-requisite for successful fertilisation and although their temporal and spatial sequences are not yet fully clarified, they involve numerous molecules in form of ligand-substrate complexes, ion current changes, and intracellular messenger pathway mobilization [24,74,75].

The basic mechanism of fertilisation has been widely debated, at present there are two main hypotheses as to how the spermatozoon triggers the oocyte into activation [24]. The first points on the binding of the spermatozoon to an oocyte membrane receptor whose signal is in turn transduced by a G-protein mechanism. The contrasting idea suggests that the spermatozoon contains a soluble factor that is released into the oocyte cytoplasm following the gamete fusion [76,77]. Both the mechanisms have been supported by experimental evidence, however in the last decade accumulating evidence indicate that the sperm factor hypothesis is more feasible. Other potential candidates were proposed by Parrington [78] to be a $33 \mathrm{KDa}$ molecular mass protein and/or a truncated form of the c-kit tyrosine kinase receptor [79]. At present it has been well documented that the phospholipase Czeta is soluble factor in mammals. However, many investigators are still working to clarify the molecular nature of sperm factor in invetebrates [80,81].

Embryo development. Successful fertilisation drives the oocyte into meiosis completion and exit and the formation of the zygote. This represents the first diploid cell of a new organism that divides by mitosis into a number of smaller cells named blastomeres. This process is the cleavage and is different depending on the species. Early cleavages are often synchronous, but when synchronism is lost, the blastomeres become arranged in layers or groups that mark their specific differences resulting from an unequal distribution of cytoplasmic components and/or from induction from neighboring cells. The blastomere nuclei are in fact subjected to a cytoplasmic environment that in turn affects gene activity. This triggers the programme of development that gives rise to the cell lines, e.g. the future embryo tissue (nerve, muscle, epidermis etc.). Transition from maternal gene products to the new individuals 
gene products takes place at different stages of division depending on the species. The first steps of embryogenesis share common characteristics among species (blastulation, gastrulation, neurulation), however the late events leading to formation of the new individual is totally different, e.g. the formation of swimming larvae and metamorphosis occurring in sea water in marine animals $v s$ embryo implantation in mammals occurring in utero.

Although a large volume of literature deals with developmental biology, this is a very complex step-by step process that is difficult to summarize [82,83].

\subsection{Marine Drugs}

Before describing the action of marine drugs on reproductive mechanisms it is worth to mentioning that most, if not all, marine invertebrates harbour microorganisms that include bacteria, cyanobacteria and fungi within their tissues extra- and intracellular space $[84,85]$. The relationship between marine invertebrates and marine microorganisms that may serve as food or that live either permanently or temporarily inside of marine macroorganisms are highly complex and far from being well understood [85-87]. Microorganisms not only serve as food for filter feeders or (in the case of cyanobacteria and chemoautotrophic bacteria) enrich the diet of their hosts by carbon and nitrogen fixation, but may perhaps also be involved in the biosynthesis of natural products [88]. So, it is clear that there is often a difficulty in clarifying the real producer of a marine compound.

In this review, we have classified marine natural products in two groups: i) compounds with known and tested impact on reproduction processes; ii) compounds with plausible impact on reproductive processes, chosen on the basis of their molecular mechanisms or targets. For convenience, we describe the origin of the drugs on the basis of the zoological scale order.

\subsubsection{Marine Natural Products Affecting Reproduction}

A limited number of studies have suggested that some of these compounds may have ecological roles as allelochemicals, specifically including compounds that may inhibit competing species. These allelochemicals may also play a role in defense against potential predators and grazers, particularly aquatic invertebrates and their larvae [89].

In the endless fight between predator and prey, the latter does not play the role of passive victim. Beyond direct defense, characterized by a series of mechanisms to avoid being killed, prey have also developed indirect long-term defenses, a sort of preventive war against predators: in fact, by producing antiproliferative compounds many organisms are able to regulate the population dynamics of their marine predators, in particular, interfering with some crucial processes of their reproductive cycle, such as: maturation, fertilisation, and early embryo development.

Cyanobacteria are Gram-negative bacteria capable of producing a wide range of potent toxins as secondary metabolites, i. e. the cyanotoxins, whose action is still rather unknown [90,91]. On the contrary, other bacteria produce widely known marine neurotoxins; tetrodotoxin (TTX) is one of these; it is a voltage-gated sodium current blocker and a major toxic component contained in pufferfish of the Family Tetraodontidae. Animals containing TTX are not limited to certain species of puffer. A wide variety of marine and terrestrial animals are now known to have TTX, including, but not limited 
to, pufferfish, salamanders, frogs, horseshoe crabs, xanthid crabs, blue-ringed octopus, and starfish [92]. In the pufferfish, TTX is concentrated in the ovary and liver, but other organs including skin, intestine, and muscle contain TTX in some species of puffer. The reason for such a wide distribution is that TTX is not produced by the puffer fish, but is produced by certain species of bacteria including Vibrio sp. and comes to be in the animals through the food chain [93-96]. As demonstrated in the ascidian Ciona intestinalis, inhibition of sodium currents at the time of fertilisation current generation gave rise to a high percentage of anomalous embryos, in which the spatial orientation at the 8/16-cell stage is lost [14].

The difficulty in identifying the real producer is clear also for another drug, maitotoxin (MTX), which is an extremely potent toxin obtained from the marine dinoflagellate Gambierdiscus toxicus and involved in ciguatera poisoning. MTX was previously detected in the viscera of maito (a small herbivorous fish, Ctenochaetus striatus, called "maito" in Tahiti), but further studies [97,98] found a good correlation between dinoflagellates in the gut contents and the toxicity of the viscera. The dinoflagellate turned out to represent both a new genus and new species, and it was named Gambierdiscus toxicus [99]. This toxin is a powerful activator of changes in the intracellular calcium concentration and it induces a potassium release from the oocytes simultaneously with a sodium entry into unfertilised eggs, although experimental evidence suggests that MTX has no ionophoretic activity per se [100-103]. MTX inhibits sea urchin egg fertilisation in a dose-dependent manner but, maybe, ion transport perturbations are probably not the direct cause of fertilisation inhibition which could be related to a modification of the plasma membrane of the female gametes by this hydrophilic toxin [101]. A different effect has been found in mouse, where the results suggest that putative channels activated by MTX may be involved in the calcium influx required for mouse sperm acrosome reaction [103].

Many marine drugs represent a useful tool for studying cellular processes: one of the most famous is okadaic acid (OA): the latter acts as a potent inhibitor of protein phosphatases [104] and has turned out to be a valuable tool for the study of phosphorylation based processes of cellular signaling [105]. The protein serine/threonine phosphatases are a unique family of enzymes that catalyze the specific dephosphorylation of phosphoserine or phosphothreonine residues in many cell types. The potent activity of OA is remarkably conserved across phyla: this toxin inhibits phosphatase activity in mammals, yeast, and higher plants [106]. OA was initially isolated and characterized from the sponges Halichondria okadai and H. melanodocia [107]. However, it was later shown to be produced by dinoflagellates of the genera Prorocentrum and Dinophysis [104,108-110] and is now considered to be of dietary origin rather than a "true" sponge metabolite in terms of its biosynthetic origin. The function of OA in sponges is not well understood. Studies by Wiens et al. [111] have provided evidence for at least two putative roles of OA within the sponge Suberites domuncula. At low concentrations, OA triggers a MAP kinase p38-regulated defense system against bacteria. At elevated concentrations, OA acts as an apoptogen and promotes expression of the proapoptotic caspase gene with a simultaneous down-regulation of the expression of the anti-apoptotic Bcl-2 homolog gene. In subsequent studies of S. domuncula, Schroder et al. [112] suggested that OA may serve as a defense molecule by inducing apoptosis in symbiotic or parasitic annelids. [113]. As protein phosphatase specific inhibitor, OA has previously been used to stimulate chromatin condensation and premature germinal vesicle breakdown in invertebrate and vertebrate oocytes [114-123]. 
Like TTX, brevetoxins are also voltage-gated sodium channel inhibitors, but these marine toxins are produced by the dinoflagellate Karenia brevis. Kimm-Brinson and Ramsdell [124] suggested that the larvae of medaka fish (Oryzias latipes), but not the eggs, are susceptible to Karenia brevis. In contrast, an earlier study with the sea urchin (Lytechinus variegatus) reported that lysates of K. brevis administered to eggs did induce developmental abnormalities [125]. This study found that sperm motility, egg fertilisation, and development through the blastula stage were unaffected; however, mortality and developmental abnormalities occurred in about $50 \%$ in embryos at gastrula stage and $80 \%$ in embryos at pluteus stage. The reason for the difference between the study with the red drum eggs and the sea urchin eggs may result from the use of $K$. brevis cells and lysates. The persistence of red tides from the late autumn until early spring has suggested that the spawning of some marine species may be subject to the adverse effect of red tide toxins. Steidinger et al. [126] also emphasized the need for attention to the effects of red tide outbreaks on migratory species, as many species seek estuaries for breeding and nursery grounds. Based on studies with other classes of fat-soluble contaminants, somatic stores of toxin in fish are transferred during oogenesis and lead to larval toxicity [127].

Figure 1. Effect of diatom-derived aldheyde 2-trans-4-trans-decadienal (DD) on fertilisation currents recorded in the whole-cell voltage clamp configuration in Ciona intestinalis oocytes. a: normal fertilisation current; b: oocytes incubated in acetaldehyde and then fertilised showed a normal fertilisation current similar to the control; c: oocytes incubated in the diatom aldehyde DD $(1.5 \mu \mathrm{g} / \mathrm{mL})$ and then fertilised showed $50 \%$ reduction in fertilisation current amplitude; $d$ : oocytes incubated in more concentrated DD ( $2 \mu \mathrm{g} / \mathrm{mL}$ ) and then fertilised showed complete inhibition of the fertilisation current. Modified from Tosti et al. [142].

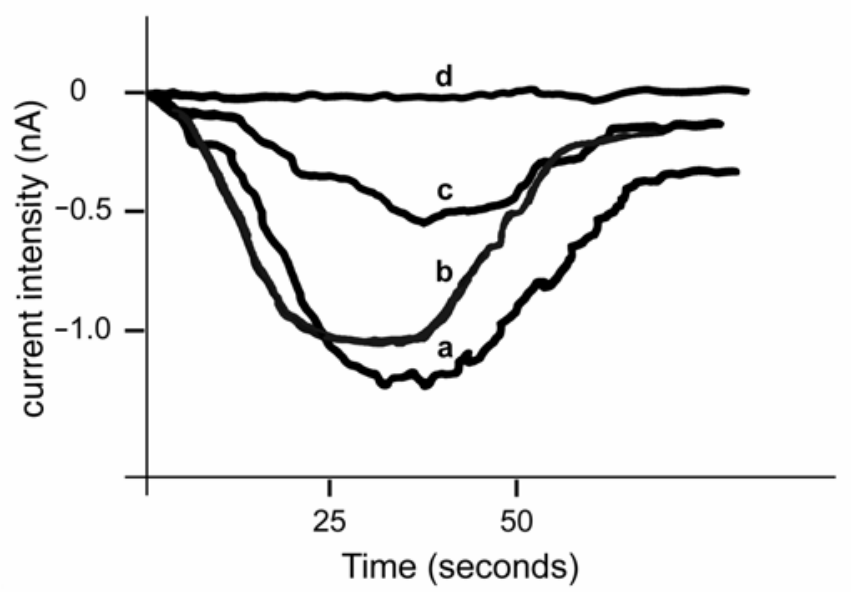

K. brevis red tides have been associated with mortality events of many aquatic animals including finfish, sea turtles, and sea birds during their adult stages [126,128-135]. These animals have been known to bioaccumulate substantial body burdens of contaminants at times, and in certain cases transfer toxicity to offspring during oogenesis. Given the similarity of developmental processes found between higher and lower vertebrates, teratogenic effects of brevetoxins have the potential to occur among different phylogenetic classes [124]. 
The last 2 decades have seen much controversy concerning the negative impacts that consumption of diatoms may have upon copepods. Despite some contrasting data [136], diatom-derived aldehydes have been shown to interfere with reproductive mechanism in copepods [137-139] and polychaetes and echinoderms [140,141]. In the ascidian Ciona intestinalis, 2-trans-4-trans-decadienal (DD) and 2-trans-4-cis-7-cis-decatrienal (DT) inhibit the fertilisation current (Figure 1) which is generated in oocyte upon interaction with the spermatozoon. In particular, DD may have a dual effect on reproductive processes, influencing primary fertilisation events such as gating of fertilisation channels and secondary processes such as actin reorganization which is responsible for the segregation of cell lineages. In the same study, DD altered actin filaments and mitocondrial migration after contraction, leading to a disturbance in cleavage formation (Figure 2A). However, DD also induced larval teratogeny at low concentrations (Figure 2B), possibly due to actin perturbation [142].

Figure 2. A: Percentage reduction of first cleavage of Ciona intestinalis oocytes incubated 10 minutes at different concentrations of DD and then fertilised. B: Percentage of embryos that reached the larval stage when exposed to different concentrations of DD. Dark shading shows the percentage of abnormal larvae. Light shading shows the percentage of normal larvae. Insert: top panel shows a normally developed C. intestinalis larva 24 hours after fertilisation. Bottom panel: various degrees of malformations such as stunted and elongated tail, lack of sensory organ pigmentation, blockage at the 118-cell stage (gastrula). From Tosti et al. [142].
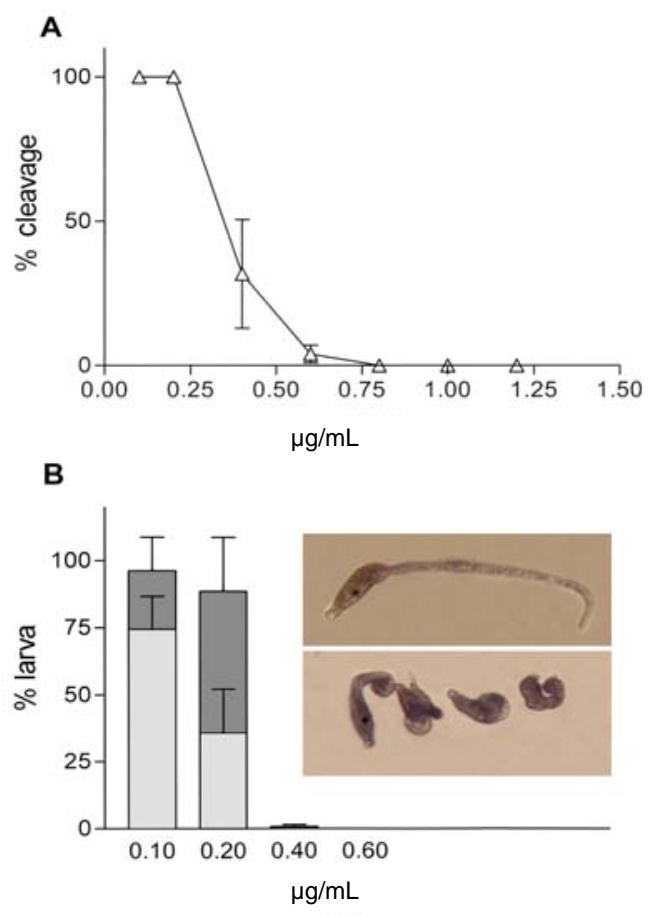

Domoic acid (DA) is produced by red alga Chondria armata and planktonic diatoms of the genus Pseudo-nitzschia, [143]. Over the last decade, reproductive failure in California sea lions has been increasingly associated with harmful algal blooms, most notably DA produced by Pseudo-nitzschia spp. [144-146]. The food web plays the primary role in the transmission of DA from Pseudo-nitzschia blooms to the California sea lion $[144,147]$. Common vectors are pelagic planktivorous fish, which 
accumulate DA-containing diatoms in their gut exceeding toxin concentrations of one part per thousand, exceptionally high levels for a natural toxin [147,148]. Additionally, Pseudo-nitzschia, which form long chains of cells, will sink to the ocean floor where the DA effectively infiltrates the benthic food web and provides an additional source of vectoring [149]. At the level of the receptor in the brain, DA binds to kainate subtypes of ionotropic glutamate receptors to induce excitotoxicity by release of glutamate and activation of $N$-methyl-D-aspartate ionotropic glutamate receptors [150]. DA crosses the placenta, readily enters the neonatal brain and is retained in the amniotic fluid [151]. The early fetal brain is electrically silent, but expresses levels of ionotropic glutamate receptors that guide the migration of neurons to the appropriate brain regions and facilitate in the formation correct synapses. DA, which is normally cleared rapidly by renal filtration in adult animals, is more toxic to animals in utero because of a longer residence time in the fetal-maternal unit and greater access to the fetal brain [143].

The effect of DA in invertebrates is also known. As a result of the DA exposure, larval growth of king scallop, Pecten maximus, measured in terms of shell length and the appearance of the eye-spot, and larval survival were significantly compromised. The negative effect of DA exposure suggests that this toxin could possibly influence natural recruitment in $P$. maximus, and it may be necessary to protect hatchery-cultured scallop larvae from DA during toxic Pseudo-nitzschia blooms [152].

Embryo development is blocked by several drugs isolated from algae: caulerpenyne does not affect the microfilament-dependent processes of fertilisation and cytokinesis and allows the beginning of mitosis, but prevents normal DNA replication and results in metaphase-like arrest of sea urchin embryos [153]; stypoldione uncouples cytokinesis from mitosis at the lowest effective concentrations and, although it can disrupt microtubules at relatively higher concentrations, it inhibits cell division at the lowest effective concentrations by a selective action on cytokinesis through a mechanism that does not appear to involve disassembly of microtubules [154].

Sometimes it happens that the same compound may have several contrasting applications: for example, a sulfono glycolipid (S-ACT-1) isolated from Gelidiella acerosa, a Sri Lankan marine red alga, has a potent human sperm motility stimulating activity in vitro and has the potential to be developed into a sperm stimulant [155], but crude extracts from the same species showed elevated post-implantation loss. Since post-coital contraceptive activity of another red alga, Gracilaria corticata, was due to enhanced pre-implantation loss, marine red algae could represent a useful source to be harvested for potential post-coital contraceptive drugs [156].

Williamson et al. [157] compared the effects of chemical cues from host algae on different life history stages of the sea urchin Holopneustes purpurascens. In sublittoral habitats, H. purpurascens occurred primarily on two algal hosts: red alga (Delisea pulchra) and kelp (Ecklonia radiata). Sea urchin larvae rapidly metamorphosed in the presence of $D$. pulchra, but metamorphosis was delayed or absent in the presence of E. radiata. D. pulchra produces a polar chemical inducer of metamorphosis not found in E. radiata. In contrast to larval metamorphosis, feeding and performance of juvenile and adult sea urchins were considerably worse on $D$. pulchra than on E. radiata.

To our knowledge, there are just few marine drugs that affect gamete maturation by interacting with the cytoskeleton [158-160]: among them, jasplakinolide, a marine compound from sponges, was found to arrest oocytes in vitro maturation acting as a microfilament inhibitor, this also affects fertilisation in mice [161,162]; theonellapeptolide Ie, from Petrosa species, induced malformed 
maturation through disturbance of cortical F-actin distribution [158]; also strongylophorines, isolated from Strongylophora strongylata, inhibited the maturation of starfish oocytes by affecting actin [160].

Other marine toxins, the latrunculins, produced by certain sponges, including genus Latrunculia, inhibit the microfilament-mediated processes during fertilisation, cleavage and early development in sea urchins and mice [163], even more potent than the cytochalasins [164].

However, not all the compounds from the sponge have the same target: for example, (-)-10-epiaxisonitrile-3, a spirocyclic sesquiterpene isocyanide obtained from the marine sponge Geodia exigua, immobilized sperm of sea urchin and starfish and in turn block fertilisation, by inhibiting the phosphocreatine shuttle participating in the high-energy phosphate metabolism [165]; theonellapeptolide IId, isolated from Theonella swinhoei, prevented fertilisation of sea urchin while has no effect on early embryonic development of fertilised eggs [166]; also jaspisin, isolated from the extract of a marine sponge, Jaspis species, has different properties: it is a selective inhibitor of exoplasmic membrane fusion in echinoderms, blocking fusion between the sperm acrosomal process and the egg plasma membrane, and also embryo hatching [167-169]. Similarly to jaspisin, but differently from 10-epi-Axisonitrile-3, there are other inhibitors of echinoderm fertilisation isolated from sponge, callyspongins $\mathbf{A}$ and $\mathbf{B}$ [170] and halenaquinol sulfate [171,172], that are able to inhibit sperm-egg fusion without affecting sperm motility [165]. Calyculin-A, originally derived from the marine sponge Discodermia calyx, is similar to okadaic acid in its potent inhibition of protein phosphatases and thus in its impact on reproduction [173,174].

Bacteria, algae and sponges are not the only source of marine products: Agius et al. [175] demonstrated that under illumination bonellin, a compound isolated from Bonellia viridis [176], causes depression of oxygen uptake by spermatozoa and developmental arrest of echinoid and Bonellia eggs. The effect on the eggs may primarily be due to the crosslinking of membrane proteins and to the formation of peroxydase that results in the cytolysis of the unfertilised eggs and in the inhibition of cleavage [177]. Bonellin is able to arrest the motility of swimming larvae of $C$. intestinalis, but, since the fibrillar structures appear to be unaltered, also this impact seems a consequence of membrane modifications [178].

Recently, spermicidal activity has been found in sea cucumber Bohadschia vitiensis whole-body extracts followed by isolation and characterization of bioactive molecule, bivittoside $\mathbf{D}$, able to induce human sperm membrane permeabilization [179].

Even some early chordates are supposed to be a promising source for marine drugs affecting reproduction processes: methoxyconidiol, extracted from the ascidian Aplidium aff. densum [180], inhibits the cleavage of sea urchin Sphaerechinus granularis and Paracentrotus lividus fertilised eggs: infact, it disrupts M-phase progression and completely blocks cytokinesis without having any effect on DNA replication, most likely by affecting microtubule dynamics [181]. In Table 1, we provide a summary of the significant data described above. 
Table 1. Summary of significant data reported in the text.

\begin{tabular}{|c|c|c|c|}
\hline Drug & Source & Target - Impact & References \\
\hline Tetrodotoxin & $\begin{array}{l}\text { Bacteria including } \\
\text { Vibrio sp. }\end{array}$ & $\begin{array}{l}\text {-Voltage-gated sodium channels; } \\
\text { - Inhibition of fertilisation current in C. intestinalis; } \\
\text { teratogenic effect }\end{array}$ & {$[14,96,200]$} \\
\hline Maitotoxin & $\begin{array}{l}\text { Dinoflagellate } \\
\text { Gambierdiscus toxicus }\end{array}$ & $\begin{array}{l}\text { - Cationic channel } \\
\text { - Mouse acrosome reaction; inhibition of sea urchin egg } \\
\text { fertilisation }\end{array}$ & {$[101,103]$} \\
\hline Okadaic acid & $\begin{array}{l}\text { Dinoflagellates } \\
\text { Prorocentrum lima and } \\
\text { Dinophysis spp. }\end{array}$ & $\begin{array}{l}\text { - Protein phosphatases; } \\
\text { - Inhibition of phosphorylation based processes of cellular } \\
\quad \text { signaling }\end{array}$ & {$[104,123]$} \\
\hline Brevetoxin & $\begin{array}{l}\text { Dinoflagellate Karenia } \\
\text { brevis }\end{array}$ & $\begin{array}{l}\text {-Voltage-gated sodium channels; } \\
\text { - Teratogenic effect }\end{array}$ & {$[124]$} \\
\hline $\begin{array}{l}\text { 2-trans,4-trans } \\
\text { Decadienal }\end{array}$ & Diatoms & $\begin{array}{l}\text { - Fertilisation current; } \\
\text { - Inhibition of embryonic development and fertilisation in } \\
\text { broadcast spawning marine invertebrates }\end{array}$ & {$[140,142]$} \\
\hline Domoic acid & $\begin{array}{l}\text { Alga Chondria armata } \\
\text { Diatom Pseudo- } \\
\text { nitzschia }\end{array}$ & $\begin{array}{l}\text { - Ionotropic glutamate receptors; } \\
\text { - Neurotoxicity; reduction of larval growth and survival in } \\
\text { P. maximus; reproductive failure in California sea } \\
\text { lions. }\end{array}$ & {$[143,152]$} \\
\hline Caulerpenyne & Alga Caulerpa taxifolia & $\begin{array}{l}\text { - Microtubules; } \\
\text { - Inhibition of first cell division }\end{array}$ & {$[153]$} \\
\hline Stypoldione & $\begin{array}{l}\text { Alga Stypopodium } \\
\text { zonale }\end{array}$ & $\begin{array}{l}\text { - Sulfhydryl groups of proteins } \\
\text { - Inhibition of cytokinesis in sea urchin embryos }\end{array}$ & {$[154]$} \\
\hline $\begin{array}{l}\text { Sulfonoglycolipid } \\
\text { S-ACT-1 }\end{array}$ & Alga Gelidiella acerosa & $\begin{array}{l}\text { - Sperm } \\
\text { - Stimulation of sperm motility }\end{array}$ & [155] \\
\hline Crude extract & $\begin{array}{l}\text { Alga Gracilaria } \\
\text { corticata, }\end{array}$ & - Increase of pre-implantation loss in femal rats & {$[156]$} \\
\hline Crude extract & Alga Gelidiella acerosa & - Increase of post-implantation loss in female rats & {$[156]$} \\
\hline Jasplakinolide & $\begin{array}{l}\text { Sponge Jaspis } \\
\text { johnstoni }\end{array}$ & $\begin{array}{l}\text { - Actin; } \\
\text { - Arrest of in vitro maturation }\end{array}$ & {$[161,162]$} \\
\hline $\begin{array}{l}\text { Theonellapeptolide } \\
\text { Ie }\end{array}$ & Sponge Petrosia & $\begin{array}{l}\text { - Cortical F-actin distribution; } \\
\text { - Abnormal maturation }\end{array}$ & {$[158]$} \\
\hline Strongylophorine & $\begin{array}{l}\text { Sponge Strongylophora } \\
\text { strongylata }\end{array}$ & $\begin{array}{l}\text {-Actin; } \\
\text {-Inhibition of the maturation of starfish oocytes }\end{array}$ & {$[160]$} \\
\hline Latrunculin & $\begin{array}{l}\text { Sponge Latrunculia } \\
\text { magnifica }\end{array}$ & $\begin{array}{l}\text { - Microfilament; } \\
\text { - Inhibition of microfilament-mediated processes during } \\
\text { fertilisation, cleavage and early development in sea } \\
\text { urchins and mice. }\end{array}$ & {$[163]$} \\
\hline $\begin{array}{l}(-)-10-e p i-A x i s o- \\
\text { nitrile-3 }\end{array}$ & Sponge Geodia Exigua & $\begin{array}{l}\text { - Phosphocreatine shuttle; } \\
\text { - Sea urchin and starfish sperm immobilization }\end{array}$ & {$[165]$} \\
\hline $\begin{array}{l}\text { Theonellapeptolide } \\
\text { IId }\end{array}$ & $\begin{array}{l}\text { Sponge Theonella } \\
\text { swinhoei }\end{array}$ & - Inhibition of fertilisation of the sea urchin & {$[166]$} \\
\hline Jaspisin & Sponge Jaspis sp. & $\begin{array}{l}\text { - Exoplasmic membrane fusion; } \\
\text { - Block fusion between sperm acrosomal process and egg } \\
\text { plasma membrane; block of embryo hatching }\end{array}$ & [167-169] \\
\hline
\end{tabular}


Table 1. Cont.

\begin{tabular}{|c|c|c|c|}
\hline $\begin{array}{l}\text { Callyspongins A } \\
\text { and B }\end{array}$ & $\begin{array}{l}\text { Sponge Callyspongia } \\
\text { truncata }\end{array}$ & - Inhibition of sperm-egg fusion & [170] \\
\hline $\begin{array}{l}\text { Halenaquinol } \\
\text { sulfate }\end{array}$ & $\begin{array}{l}\text { Sponge Xestospongia } \\
\text { sapra }\end{array}$ & - Inhibition of sperm-egg fusion & {$[171,172]$} \\
\hline Calyculin A & $\begin{array}{l}\text { Sponge Discodermia } \\
\text { calyx }\end{array}$ & $\begin{array}{l}\text { - Protein phosphatases } \\
\text { - Modulation of phosphorylation based processes of } \\
\text { cellular signalling }\end{array}$ & [174] \\
\hline Bonellin & Echiura Bonellia viridis & $\begin{array}{l}\text { - Membrane proteins; } \\
\text { - Formation of peroxydase; cytolysis of unfertilised eggs, } \\
\quad \text { inhibition of cleavage and of larval motility }\end{array}$ & {$[178]$} \\
\hline Bivittoside D & $\begin{array}{l}\text { Sea cucumber } \\
\text { Bohadschia vitiensis }\end{array}$ & $\begin{array}{l}\text { - Sperm; } \\
\text { - Membrane permeabilization; spermicide activity in } \\
\text { human }\end{array}$ & [179] \\
\hline Methoxyconidiol & $\begin{array}{l}\text { Ascidian Aplidium aff. } \\
\text { densum }\end{array}$ & $\begin{array}{l}\text { - Microtubules; } \\
\text { - Inhibition of cleavage }\end{array}$ & {$[180,181]$} \\
\hline
\end{tabular}

\subsubsection{Potential Impact of Marine Drugs}

As described above, reproduction is a complex process characterized by many crucial steps. It is clear that every marine compound able to affect in some way one of these events could affect reproduction either in natural setting and in vitro. A good example to better understand the huge potential of marine organisms as drug source is given by marine sponges. The latter have been considered to be a gold mine during the past 50 years, with respect to the diversity of their secondary metabolites [182]. A huge amount of marine products has been described [183-187] and sponges, in particular, are the source of more than 5,300 different products. Every year hundreds of new compounds are being discovered [184-186], leading to identification of novel therapeutic agents showing a broad spectrum of pharmacological activity; therefore, more marine natural products will probably become potential leads for clinical development as novel therapeutic agents for the treatment of multiple disease categories [188-190].

Marine compounds showed different effects on many molecules that are in different ways involved in reproduction, for example, they inhibit protein kinase C [113,191-193], calcium [194-196], sodium [197-201] and potassium channels [202-206]. Similarly, other targets are $\mathrm{IP}_{3}$ receptors, endoplasmic reticulum calcium pumps [207], microtubules [208-216]; microfilaments [217-221]; and plasma membrane [222,223].

Even though this is not proved yet, we may hypothesize their plausible impact on reproduction on the basis of their molecular targets, either in vivo and in vitro. Over the last few decades significant efforts have been made, by both pharmaceutical companies and academic institutions, to isolate and identify new marine-derived natural products. Because of the diversity in ocean life many new potentially interesting compounds are continuously being discovered.

Despite the risks associated with marine toxins, such as food poisoning or harmful algal blooms, these biogenic compounds have proven their advantage and potential in several fields, particularly as new therapeutic agents for a variety of diseases: in fact, marine ecosystem is an enormously rich 
source of natural products with promising therapeutic usefulness in oncology, providing anticancer agents with novel mechanisms of action [224-227].

This review reports current understanding of the impacts of compounds from marine organisms on the main reproductive processes and some of their specific mechanisms underlying gametogenesis, fertilisation and very early embryo development. Although most of the data provide evidence that such compounds adversely affect reproductive success, marine drugs may represent a wide source with potential application in improving reproductive fitness.

\section{Acknowledgments}

We thank Euan R. Brown for helpful comments; thanks are also due to G. Gargiulo and G. Lanzotti for the computer graphics.

\section{References}

1. Yanagimachi, R. Mammalian fertilization. In The Physiology of Reproduction; Knobil, E., Neil, J., Eds.; Raven Press: New York, NY, USA, 1994; Vol. 1, pp. 189-317.

2. Eppig, J.J. Coordination of nuclear and cytoplasmic oocyte maturation in eutherian mammals. Reprod. Fertil. Dev. 1996, 8, 485-489.

3. Masui, Y. A quest for cytoplasmic factors that control the cell cycle. Prog. Cell Cycle Res. 1996, 2, 1-13.

4. Whitaker, M.; Patel, R. Calcium and cell cycle control. Development 1990, 108, 525-542.

5. Whitaker, M. Control of meiotic arrest. Rev. Reprod. 1996, 1, 127-135.

6. Kishimoto, T. Cell-cycle control during meiotic maturation. Curr. Opin. Cell Biol. 2003, 15, 654-663.

7. Haccard, O.; Jessus, C. Oocyte maturation, Mos and cyclins-A matter of synthesis: Two functionally redundant ways to induce meiotic maturation. Cell Cycle 2006, 5, 1152-1159.

8. Ducibella, T.A.; Anderson, D.F.; Albertini, F.; Aalberg, J.; Rangarajan, S. Quantitative studies of changes in cortical granule number and distribution in the mouse oocyte during maturation. Dev. Biol. 1988, 130, 184-197.

9. Wessel, G.M.; Brooks, J.M.; Green, E.; Haley, S.; Voronina, E.; Wong, J.; Zaydfudim, V.; Conner, S. The biology of cortical granules. Int. Rev. Cytol. 2001, 209, 117-206.

10. Prodon, F.; Chenevert, J.; Sardet, C. Establishment of animal-vegetal polarity during maturation in ascidian oocytes. Dev. Biol. 2006, 290, 297-311.

11. Hake, L.E.; Richter, J.D. Translational regulation of maternal mRNA. Biochem. Biophys. Acta 1997, 1332, 31-38.

12. Carroll, $\mathrm{J} . \mathrm{Na}^{+}-\mathrm{Ca}^{2+}$ exchange in mouse oocytes: Modifications in the regulation of intracellular free $\mathrm{Ca}^{2+}$ during oocyte maturation. J. Reprod. Fert. 2000, 118, 337-342.

13. Cuomo, A.; Di Cristo, C.; Di Cosmo, A.; Paolucci, M.; Tosti, E. Calcium currents correlate with oocyte maturation during the reproductive cycle in Octopus vulgaris. J. Exp. Zool. A, 2005, 303, 193-202. 
14. Cuomo, A.; Silvestre, F.; De Santis, R.; Tosti, E. $\mathrm{Ca}^{2+}$ and $\mathrm{Na}^{+}$current patterns during oocyte maturation, fertilization, and early developmental stages of Ciona intestinalis. Mol. Reprod. Dev. 2006, 73, 501-511.

15. Silvestre F.; Cuomo A.; Tosti, E. Ion current activity and molecules modulating maturation and growth stages of ascidian (Ciona intestinalis) oocytes. Mol. Repodr. Dev. 2009, 76, 1084-1093.

16. Homa, S. Calcium and meiotic maturation of the mammalian oocyte. Mol. Reprod. Dev. 1995, 40, 122-134.

17. Gilchrist, R.; Thompson, J.G. Oocyte maturation: Emerging concepts and technologies to improve developmental potential in vitro. Theriogenology, 2007, 67, 6-15.

18. Richard, F.J. Regulation of meiotic maturation. J. Animal. Sci. 2007, 85, E4-E6.

19. Vaccari, S.; Horner, K.; Mehlmann, L.M.; Conti, M. Generation of mouse oocytes defective in cAMP synthesis and degradation: Endogenous cyclic AMP is essential for meiotic arrest. Dev. Biol. 2008, 316, 124-134.

20. Masui, Y. From oocyte maturation to the in vitro cell cycle: The history of discoveries of Maturation-Promoting Factor (MPF) and Cytostatic Factor (CSF). Differentiation 2001, 69, $1-17$.

21. Russo, G.L.; Kyozuka, K.; Antonazzo, L.; Tosti, E.; Dale, B. Maturation promoting factor in ascidian oocytes is regulated by different intracellular signals at meiosis I and II. Development 1996, 122, 1995-2003.

22. Kishimoto, T. Cell cycle arrest and release in starfish oocytes and eggs. Semin. Cell Dev. Biol. 1998, 9, 549-557.

23. Yamashita, M.; Mita, K.; Yoshida, N.; Kondo, T. Molecular mechanisms of the initiation of oocyte maturation: General and species-specific aspects. Prog. Cell Cycle Res. 2000, 4, 115-129.

24. Tosti, E. Calcium ion currents mediating oocyte maturation events. Reprod. Biol. Endocrinol. 2006, 4, 26.

25. Whitaker, M. Calcium at fertilization and in early development. Physiol. Rev. 2006, 86, $25-88$.

26. Carroll, J.; Swann, K.; Whittingham, D.; Whitaker, M. Spatiotemporal dynamics of intracellular $\left[\mathrm{Ca}^{2+}\right]_{\mathrm{i}}$ oscillations during the growth and meiotic maturation of mouse oocytes. Development 1994, 120, 3507-3517.

27. Tombes, R.M.; Simerly, C.; Borisy, G.G.; Schatten, G. Meiosis, egg activation, and nuclear envelope breakdown are differentially reliant on $\mathrm{Ca}^{2+}$, whereas germinal vesicle breakdown is $\mathrm{Ca}^{2+}$ independent in the mouse oocyte. J. Cell Biol. 1992, 117, 799-811.

28. Roth, Z.; Hansen P.J. Disruption of nuclear maturation and rearrangement of cytoskeletal elements in bovine oocytes exposed to heat shock during maturation. Reproduction 2005, 129, 235-244

29. Sun, Q.Y.; Schatten, H. Regulation of dynamic events by microfilaments during oocyte maturation and fertilization. Reproduction 2006, 131, 193-205.

30. Tosti, E. Sperm activation in species with external fertilization. Zygote 1994, 2, 359-361.

31. Stratmhann, R.R. Why life histories evolve differently in the sea. Soc. Integ. Comp. Biol. 1990, 30, 197-207. 
32. Levitan, D.R.; Young, C.M. Reproductive success in large populations: Empirical measures and theoretical predictions of fertilization in the sea biscuit Clypeaster rosaceus. J. Exp. Mar. Biol. Ecol. 1995, 190, 221-241.

33. Sewell, M.A.; Levitan, D.R. Fertilization success during a natural spawning of the dendrochirote sea cucumber Cucumaria miniata. Bull. Mar. Sci. 1992, 51, 161-166.

34. Mead, K.S.; Denny, M.W. The effects of hydrodynamic shear stress on fertilization and early development of the purple sea urchin Strongylocentrotus purpuratus. Biol. Bull. 1995, 188, 46-56.

35. Thomas F. Physical properties of gametes in three sea urchin species. J. Exp. Biol. 1994, 194, 263-284.

36. Dale, B. Fertilization in animals; Edward Arnold Ed.; The Camelot Pres Ltd: London, UK, 1983.

37. Aitken, R.J. Sperm function tests and fertility. Int. J. Androl. 2006, 29, 69-75

38. Breitbart, H. Signaling pathways in sperm capacitation and acrosome reaction. Cell. Mol. Biol. 2003, 49, 321-327.

39. Stein, K.K.; Primakoff, P; Myles, D. Sperm-egg fusion: Events at the plasma membrane. J. Cell Sci. 2004, 1117, 6269-6274.

40. Tosti, E.; Boni, R. Electrical events during gamete maturation and fertilisation in animals and human. Hum. Reprod. Update 2004, 10, 53-65.

41. Dale, B.; DeFelice, L.J.; Taglietti, V. Membrane noise and conductance increase during single spermatozoon-egg interaction. Nature 1978, 275, 217-219.

42. Dale, B.; de Santis, A. Maturation and fertilization of the sea urchin oocyte: An electrophysiological study. Dev. Biol. 1981, 85, 474-484.

43. Dale, B.; DeFelice, L.J. Sperm-activated channels in ascidian oocytes. Dev. Biol. 1984, 101, 235-239.

44. DeFelice, L.J.; Kell, M.J. Sperm-activated currents in ascidian oocytes. Dev. Biol. 1987, 119, $123-128$.

45. Jaffe, L.A.; Gould-Somero, M.; Holland, L. Ionic mechanism of the fertilization potential of the marine worm, Urechis caupo (Echiura). J. Gen. Physiol. 1979, 73, 469-492.

46. Glahn, D.; Nuccitelli, R. Voltage-clamp study of the activation currents and fast block to polyspermy in the egg of Xenopus laevis. Dev. Growth Diff. 2003, 45, 187-197.

47. Miyazaki, S.; Igusa, Y. Fertilization potential in golden hamster eggs consists of recurring hyperpolarization. Nature 1981, 290, 702-704.

48. McCulloh, D.H.; Rexroad, C.E., Jr.; Levitan, H. Insemination of rabbit eggs is associated with slow depolarization and repetitive diphasic membrane potentials. Dev. Biol. 1983, 95, 372-377.

49. Igusa, Y.; Miyazaki, S.; Yamashita, N. Periodic hyperpolarizing responses in hamster and mouse eggs fertilized with mouse sperm. J. Physiol. 1983, 340, 633-647.

50. Gianaroli, L.; Tosti, E.; Magli, C.; Iaccarino, M.; Ferraretti, A.P.; Dale, B. Fertilization current in the human oocyte. Mol. Reprod. Dev. 1994, 38, 209-214.

51. Tosti, E.; Boni, R.; Cuomo, A. Fertilization and activation currents in bovine oocytes. Reproduction 2002, 124, 835-846.

52. Jaffe, L.A. Fast block to polyspermy in sea urchin eggs is electrically mediated. Nature 1976, $261,68-71$. 
53. Gould-Somero, M.; Jaffe, L.A.; Holland, L.Z. Electrically mediated fast polyspermy block in eggs of the marine worm, Urechis caupo. J. Cell Biol. 1979, 82, 426-440.

54. Goudeau, H.; Depresle, Y.; Rosa, A.; Goudeau, M. Evidence by a voltage clamp study of an electrically mediated block to polyspermy in the egg of the ascidian Phallusia mammillata. Dev. Biol. 1994, 166, 489-501.

55. Satoh, N. Developmental Biology of Ascidians. Cambridge University Press: New York, NY, USA, 1994.

56. Turner, P.R.; Jaffe, L.A.; Fein, A. Regulation of cortical vesicle exocytosis in sea urchin eggs by inositol 1,4,5-trisphosphate and GTP-binding protein. J. Cell Biol. 1986, 102, 70-76.

57. Stith, B.J.; Espinoza, R.; Roberts, D.; Smart, T. Sperm increase inositol 1,4,5-trisphosphate mass in Xenopus laevis eggs preinjected with calcium buffers or heparin. Dev. Biol. 1994, 165, 206215.

58. Dupont, G.; McGuinness, O.M.; Johnson, M.H.; Berridge, M.J.; Borgese, F. Phospholipase C in mouse oocytes: Characterization of beta and gamma isoforms and their possible involvement in sperm-induced $\mathrm{Ca}^{2+}$ spiking. Biochem. J. 1996, 316, 583-591.

59. Lee, S.J.; Madden, P.J.; Shen, S.S. U73122 blocked the cGMP-induced calcium release in sea urchin eggs. Exp. Cell Res. 1998, 242, 328-334.

60. Kline, D.; Kline, J.T. Repetitive calcium transients and the role of calcium in exocytosis and cell cycle activation in the mouse egg. Dev. Biol. 1992, 149, 80-89.

61. Miyazaki, S.; Shirakawa, H.; Nakada, K.; Honda, Y. Essential role of the inositol 1,4,5-trisphosphate receptor/ $\mathrm{Ca}^{2+}$ release channel in $\mathrm{Ca}^{2+}$ waves and $\mathrm{Ca}^{2+}$ oscillations at fertilization of mammalian eggs. Dev. Biol. 1993, 158, 62-78.

62. Swann, K.; Ozil, J.P. Dynamics of the calcium signal that triggers mammalian egg activation. Int. Rev. Cytol. 1994, 152, 183-222.

63. Xu, Z.; Kopf, G.S.; Schultz, R.M. Involvement of inositol 1,4,5-trisphosphate-mediated $\mathrm{Ca}^{2+}$ release in early and late events of mouse egg activation. Development 1994, 120, 1851-1859.

64. Abbott, A.L.; Ducibella, T. Calcium and the control of mammalian cortical granule exocytosis. Front. Biosci. 2001, 6, D792 -D806.

65. Malcuit, C.; Kurokawa, M.; Fissore, R.A. Calcium oscillations and mammalian egg activation. $J$. Cell Physiol. 2006, 206, 565-573.

66. Busa, W.B.; Nuccitelli, R. An elevated free cytosolic $\mathrm{Ca}^{2+}$ wave follows fertilization in eggs of the frog, Xenopus laevis. J. Cell Biol. 1985, 100, 1325-329.

67. Jaffe, L.A.; Giusti, A.F.; Carroll, D.J.; Foltz, K.R. $\mathrm{Ca}^{2+}$ signalling during fertilization of echinoderm eggs. seminars in Cell \& Dev. Biol. 2001, 12, 45-51.

68. Dumollard, R.; McDougall, A.; Rouvière, C.; Sardet, C. Fertilisation calcium signals in the ascidian egg. Biol. Cell 2004, 96, 29-36.

69. He, C.L.; Damiani, P.; Parys, J.B.; Fissore, R.A. Calcium, calcium release receptors, and meiotic resumption in bovine oocytes. Biol. Reprod. 1997, 57, 1245-1255.

70. Mehlmann, L.M.; Kline, D. Regulation of intracellular calcium in the mouse egg: Calcium release in response to sperm or inositol trisphosphate is enhanced after meiotic maturation. Biol. Reprod. 1994, 51, 1088-1098. 
71. Ducibella, T.; Huneau, D.; Angelichio, E.; Xu, Z.; Schultz, R.M.; Kopf, G.S.; Fissore, R.A.; Madoux, S.; Ozil, J.P. Egg-to-embryo transition is driven by differential responses to $\mathrm{Ca}^{2+}$ oscillation number. Dev. Biol. 2002, 250, 280-291.

72. Miyazaki, S.; Ito, M. Calcium signals for egg activation in mammals. J. Pharmacol. Sci. 2006, 100, 545-552.

73. Swann, K.; Yu, Y. The dynamics of calcium oscillations that activate mammalian eggs. Int. J. Dev. Biol. 2008, 52, 585-594.

74. Dale, B. Oocyte activation in invertebrates and humans. Zygote, 1994, 2, 373-377.

75. Runft, L.L.; Jaffe, L.A.; Mehlmann, L.M. Egg activation at fertilization: Where it all begins. Dev. Biol. 2002, 245, 237-54.

76. Wilding, M.; Dale, B. Sperm factor: What is and what I does it do? Mol. Human Reprod. 1997, 3, 269-273.

77. Swann, K.; Larman, M.G.; Saunders, C.M.; Lai, F.A. The cytosolic sperm factor that triggers $\mathrm{Ca}^{2+}$ oscillations and egg activation in mammals is a novel phospholipase C: PLCzeta. Reproduction 2004, 127, 431-439.

78. Parrington, J; Swann, K; Shevchenko, V.I.; Sesay, A.K.; Lai, F.A. Calcium oscillations in mammalian eggs triggered by a soluble sperm protein. Nature 1996, 379, 364-368.

79. Sette, C.; Bevilacqua, A.; Bianchini, A.; Mangia, F.; Geremia, R.; Rossi, P. Parthenogenetic activation of mouse eggs by microinjection of a truncated c-kit tyrosine kinase present in spermatozoa. Development 1997, 124, 2267-2274.

80. Saunders, C.M.; Larman, M.G.; Parrington, J.; Cox, L.J.; Royse, J.; Blayney, L.M.; Swann, K.; Lai, F.A. PLC zeta: A sperm-specific trigger of $\mathrm{Ca}(2+)$ oscillations in eggs and embryo development. Development 2002, 129, 3533-3544.

81. Tosti, E.; Menezo Y. Sperm induced oocyte activation. In Human Spermatozoa: Maturation, Capacitation and Abnormalities; Nova Science Publishers: Hauppage, NY, USA, in press.

82. Alberts, B.; Bray, D.; Lewis, J.; Raff, M.; Roberts, K.; Watson, J.D. Cellular mechanisms of development. In Molecular Biology of the Cell; Garland Publishing: New York, NY, USA, 1983; pp. 813-890.

83. Menezo, Y.; Renard, J.P. The life of egg before implantation. In Reproduction in Mammals and Man; Thibault, C.; Levassouf, M.C., Eds.; AHF Unter Elipses: Paris, France, 1993; pp. 350-366.

84. Vacelet, J.; Donadey, C. Electron microscope study of the association between some sponges and bacteria. J. Exp. Mar. Ecol. 1977, 30, 301-314.

85. Wilkinson, C.R. Symbiotic interactions between marine sponges and algae. In Algae and Symbioses; Reisser, W., Ed.; Biopress: Bristol, UK, 1992; pp. 112-151.

86. Hentschel, U.; Steinert, M.; Hacker, J. Common molecular mechanisms of symbiosis and pathogenesis. Trends Microbiol. 2000, 8, 226-231.

87. Steinert, M.; Hentschel, U.; Hacker, J. Symbiosis and pathogenesis: Evolution of the microbehost interaction. Naturwissenschaft 2000, 7, 1-11.

88. Proksch, P.; Edrada, R.A.; Ebel, R. Drugs from the seas - Current status and microbiological implications. Appl. Microbiol. Biotechnol. 2002, 59, 125-134. 
89. Berry, J.P.; Gantar, M.; Perez, M.H.; Berry, G.; Noriega, F.G. Cyanobacterial toxins as allelochemicals with potential applications as algaecides, herbicides and insecticides. Mar. Drugs 2008, 6, 117-146.

90. van Apeldoorn, M.E.; van Egmond, H.P.; Speijers, G.J.; Bakker, G.J. Toxins of cyanobacteria. Mol. Nutr. Food Res. 2007, 51, 7-60.

91. Duy, T.N.; Lam, P.K.S.; Shaw, G.; Connell, D.W. Toxicology and risk assessment of freshwater cyanobacterial (bluegreen algal) toxins in water. Rev. Environ. Contam. Toxicol. 2000, 163, 113-186.

92. Miyazawa, K; Noguchi, T. Distribution and origin of tetrodotoxin. J. Toxicol.Tox. Rev. 2001, 20, $11-33$.

93. Noguchi, T.; Jeon, J.K.; Arakawa, O.; Sugita, H.; Deguchi, Y.; Shida, Y.; Hashimoto, K. Occurrence of Tetrodotoxin and Anhydrotetrodotoxin in Vibrio sp. Isolated from the Intestines of a Xanthid Crab, Atergatis floridus. J. Biochem. 1986, 99, 311-314.

94. Narita, H.; Matsubara, S.; Miwa, N.; Akahane, S.; Murakami, M.; Goto, T.; Nara, M.; Noguchi, T.; Saito, T.; Shida, Y.; Hashimoto, K. Vibrio alginolyticus, a TTX-producing bacterium isolated from the starfish Astropecten polyacanthus. Bull. Japan Soc. Sci. Fish. 1987, 47, 935-941.

95. Hashimoto, K.; Noguchi, T.; Watabe, S. Microbial Toxins in Foods and Feeds; Pohland, A.E., Dowell, V.R., Jr.; Richard, J.L., Eds; Plenum Press: New York, NY, USA, 1990; pp. 159-172.

96. Naharashi, T. Tetrodotoxin: A brief history. Proc. Jpn Acad. Ser. B Phys. Biol. Sci. 2008, 84, 147-154.

97. Yasumoto, T.; Murata, M. Marine toxins. Chem. Rev. 1993, 93, 1897-1909.

98. Yasumoto, T.; Satake, M. Chemistry, Etiology and Determination Methods of Ciguatera Toxins. J. Toxicol. Tox. Rev. 1996, 15, 91-107.

99. Yasumoto, T. The Chemistry and Biological Function of Natural Marine Toxins. Chem. Rec. 2001, 1, 228-242.

100. Takahashi, M.; Ohizumi, Y.; Yasumoto, T. Maitotoxin, a $\mathrm{Ca}^{2+}$ channel activator candidate. J. Biol. Chem. 1982, 257, 7287-7289.

101. Pesando, D.; Girard, J.P.; Durand-Clément, M.; Payan, P.; Puiseux-Dao, S. Effect of maitotoxin on sea urchin egg fertilization and on $\mathrm{Ca}^{2+}$ permeabilities of eggs and intracellular stores. Biol. Cell 1991, 72, 269-273.

102. Escobar, L.I.; Salvador, C.; Martinez, M.; Vaca, L. Maitotoxin, a cationic channel activator. Neurobiology 1998, 6, 59-74.

103. Treviño, C.L.; De la Vega-Beltrán, J.L.; Nishigaki, T.; Felix, R.; Darszon, A. Maitotoxin potently promotes $\mathrm{Ca}^{2+}$ influx in mouse spermatogenic sells and sperm, and snduces the acrosome reaction. J. Cell Physiol. 2006, 206, 449-456.

104. Yasumoto, T.; Seino, N.; Murakami, Y.; Murata, M. Toxins produced by benthic dinoflagellates. Biol. Bull. 1987, 172, 128-131.

105. Dounay, A.B.; Forsyth, C.J. Okadaic acid: The archetypal serine/threonine protein phosphatase inhibitor. Curr. Med. Chem. 2002, 9, 1939-1980.

106. Cohen, P.; Holmes, C.F.B.; Tsukitani, Y. Okadaic acid: A new probe for studying cellular regulation. Trends Biochem. Sci. 1990, 15, 98-102. 
107. Tachibana, K.; Scheuer, P.; Tsukitani, Y.; Kikuchi, H.; van Engen, D.; Clardy, J.; Gopichand, Y.; Schmitz, F. J. Okadaic acid, a cytotoxic polyether from two marine sponges of the genus Halichondria. J. Am. Chem. Soc. 1981, 103, 2469-2471.

108. Murakami, Y.; Oshima, Y.; Yasumoto, T. Identification of okadaic acid as a toxic component of a marine dinoflagellate Prorocentrum lima. Bull. Jpn. Soc. Sci. Fish. 1982, 48, 69-72.

109. Zhou, J.; Fritz, L. Okadaic acid antibody localizes to chloroplasts in the DSP-toxin-producing dinoflagellates Prorocentrum lima and Prorocentrum maculosum. Phycologia 1994, 33, 455461.

110. McLachlan, J.L.; Marr, J.C.; Conlon-Kelly, A.; Adamson, A. Effects of nitrogen concentration and cold temperature on DSP-toxin concentrations in the dinoflagellate Prorocentrum lima (Prorocentrales, Dinophyceae). J. Nat. Toxins 1994, 2, 263-270.

111. Wiens, M.; Luckas, B.; Brümmer, F.; Shokry, M.; Ammar, A.; Steffen, R.; Batel, R.; DiehlSeifert, B.; Schröder, H.C.; Müller, W.E.G. Okadaic acid: A potential defense molecule for the sponge Suberites domuncula. Mar. Biol. 2003, 142, 213-223.

112. Schröder, H.C.; Breter, H.J.; Fattorusso, E.; Ushijima, H.; Wiens, M.; Steffen, R.; Batel, R.; Müller, W.E.G. Okadaic acid, an apoptogenic toxin for symbiotic/parasitic annelids in the demosponge Suberites domuncula. Appl. Environ. Microbiol. 2006, 72, 4907-4916.

113. Paul, V.J.; Arthur, K.E.; Ritson-Williams, R.; Ross, C.; Sharp, K. Chemical defenses: From compounds to communities. Biol. Bull. 2007, 213, 226-251.

114. Pondaven, P.; Cohen, P. Identification of protein phosphatases-1 and $2 \mathrm{~A}$ and inhibitor-2 in oocytes of the starfish Asterias rubens and Marthasterias glacialis. Eur. J. Biochem. 1987, 167, $135-140$.

115. Goris, J.; Hermann, J.; Hendrix, P.; Ozon, R.; Merlevede, W. Okadaic acid, a specific protein phosphatase inhibitor, induces maturation and MPF formation in Xenopus laevis oocytes. FEBS Lett. 1989, 245, 91-94.

116. Rime, H.; Ozon, R. Protein phosphatases are involved in the in vivo activation of histone HI kinase in mouse oocyte. Dev. Biol. 1990, 141, 115-122.

117. Alexandre, H.; van Cauwenberge, A.; Tsukitani, Y.; Mulnard, J. Pleiotropic effect of okadaic acid on maturing mouse oocytes. Development 1991, 112, 971-980.

118. Gavin, A.C.; Tsukitani, Y.; Schorderet-Slatkine, S. Induction of M-phase entry of prophaseblocked mouse oocytes through microinjection of okadaic acid, a specific phosphatase inhibitor. Exp. Cell Res. 1991, 192, 75-81.

119. Schwartz, D.A.; Schultz, R.M. Stimulatory effect of okadaic acid, an inhibitor of protein phosphatases, on nuclear envelope breakdown and protein phosphorylation in mouse oocytes and one-cell embryos. Dev. Biol. 1991, 145, 119-127.

120. Gavin, A.C.; Vassalli, J.D.; Cavadore, J.C.; Schorderet-Slatkine, S. Okadaic acid and p13suc1 modulate the reinitiation of meiosis in mouse oocytes. Mol. Reprod. Dev. 1992, 33, 287-296.

121. Levesque, J.T.; Sirard, M.A. Effects of different kinases and phosphatases on nuclear and cytoplasmic maturation of bovine oocytes. Mol. Reprod. Dev. 1995, 42, 114-121.

122. Sasseville, M.; Côté, N.; Guillemette, C.; Richard, F.J. New insight into the role of phosphodiesterase 3A in porcine oocyte maturation. BMC Dev. Biol. 2006, 6, 47. 
123. Swain, J.E.; Ding, J.; Brautigan, D.L.; Villa-Moruzzi, E.; Smith, G.D. Proper chromatin condensation and maintenance of histone $\mathrm{H} 3$ phosphorylation during mouse oocyte meiosis requires protein phosphatase activity. Biol. Reprod. 2007, 76, 628-638.

124. Kimm-Brinson, K.L; Ramsdell, J.S. The red tide toxin, brevetoxin, induces embryo toxicity and developmental abnormalities. Environ. Health Perspect. 2001, 109, 377-381.

125. Moon, R.T.; Morrill, J.B. The effects of Gymnodinium breve lysate on the larval development of the sea urchin Lytechinus variegatus. J. Environ. Sci. Health 1976, 11, 673-683.

126. Steidinger, K.A.; Burklew, M.A.; Ingle, R.M. The effects of Gymnodinium breve toxin on estuarine animals. In Marine Pharmacognosy; Martin, D.F., Padilla, G.M., Eds.; Academic Press: New York, NY, USA, 1973; pp. 179-202.

127. Miller, M.A. Maternal transfer of lipophilic contaminants in Salmonines to their eggs. Can. J. Fish. Aquat. Sci. 1993, 49, 1405-1413.

128. Walker, S.T. Fish mortality in the Gulf of Mexico. Proc. U.S. Natl. Mus. 1884, 6, 105-109.

129. Taylor, H.F. Mortality of fishes on the West Coast of Florida. Report of the U.S. Commissioner of Fisheries. Bureau of Fisheries Document 848. Government Printing Office: Washington, USA, 1917.

130. Davis, C.C. Gymnodinium breve: A cause of discolored water and animal mortality in the Gulf of Mexico. Bot. Gaz. 1948, 109, 358-360.

131. Gunter, G.; Williams, R.H.; Davis, C.C.; Smith, F.G.W. Catastrophic mass mortality of marine animals and coincident phytoplankton bloom on the west coast of Florida, November 1946 to August 1947. Ecol. Monogr. 1948, 8, 310-324.

132. Quick, J.A.; Henderson, G.E. Evidences of new ichthyointoxicative phenomena in Gymnodinium breve red tides. In Proceedings of the First International Conference on Toxic Dinoflagellate Blooms; LoCicero, B.R., Ed.; Massachusetts Science and Technology Foundation: Wakefield, UK, 1975; pp. 413-422.

133. Riley, C.M.; Holt, S.A.; Holt, J.; Buskey, E.J.; Arnold, C.R. Mortality of larval red drum (Sciaenops ocellatus) associated with a Ptychodiscus brevis red tide. Contrib. Mar. Sci. 1989, 31, 137-146.

134. Forrester, D.J.; Gaskin, J.M.; White, F.H.; Thompson, N.P.; Quick, J.A.; Henderson, G.E.; Woodard, J.C.; Robertson, W.D. An epizootic of waterfowl associated with a red tide episode in Florida. J. Wildl. Dis. 1977, 13, 160-167

135. Bossart, G.D.; Baden, D.G.; Ewing, R.Y.; Roberts, B.; Wright, S.D. Brevitoxicosis in manatees (Trichechus manatus latirostris) from the 1996 epizootic: Gross, histologic and mmunohistochemical features. Toxicol. Pathol. 1998, 26, 276-282.

136. Flynn, K.J.; Irigoien, X. Aldehyde-induced insidious effects cannot be considered as a diatom defence mechanism against copepods. Mar. Ecol. Prog. Series 2009, 377, 79-89.

137. Miralto, A.; Barone, G.; Romano, G.; Poulet, S.A.; Ianora, A.; Russo, G.L.; Buttino, I.; Mazzarella, G.; Laabir, M.; Cabrini, M.; Giacobbe, M.G. The insidious effect of diatoms on copepod reproduction. Nature 1999, 402, 173-176.

138. Ianora, A.; Miralto, A.; Poulet, S.A.; Carotenuto, Y.; Buttino, I.; Romano, G.; Casotti, R.; Pohnert, G.; Wichard, T.; Colucci-D'Amato, L.; Terrazzano, G.; Smetacek, V. Aldehyde 
suppression of copepod recruitment in blooms of a ubiquitous planktonic diatom. Nature 2004, 429, 403-407.

139. Buttino, I.; De Rosa, G.; Carotenuto, Y.; Mazzella, M.; Ianora, A.; Esposito, F.; Vitiello, V.; Quaglia, F.; La Rotonda, M.I.; Miralto, A. Aldehyde-encapsulating liposomes impair marine grazer survivorship. J. Exp. Biol. 2008, 211, 1426-1433.

140. Caldwell, G.S.; Olive, P.J.W.; Bentley, M.G. Inhibition of embryonic development and fertilization in broadcast spawning marine invertebrates by water-soluble diatom extracts and the diatom toxin 2-trans,4-trans-decadienal. Aquatic Toxicol. 2002, 60, 123- 137.

141. Caldwell, G.S.; Lewis, C.; Olive, P.J.; Bentley, M.G. Exposure to 2,4-decadienal negatively impacts upon marine invertebrate larval fitness. Mar. Environ. Res. 2005, 59, 405-417.

142. Tosti, E.; Romano, G.; Buttino, I.; Cuomo, A.; Ianora, A.; Miralto, A. Bioactive aldehydes from diatoms block the fertilization current in ascidian oocytes. Mol. Reprod. Dev. 2003, 66, 72-80.

143. Ramsdell, J.S.; Zabka, T.S. In utero domoic acid toxicity: A fetal basis to adult disease in the California sea lion (Zalophus californianus). Mar. Drugs 2008, 6, 262-290.

144. Scholin, C.A.; Gulland, F.; Doucette, G.J.; Benson, S.; Busman, M.; Chavez, F.P.; Cordaro, J.; DeLong, R.; de Vogelaere, A.; Harvey, J.; Haulena, M.; Lefebvre, K.; Lipscomb, T.; Loscutoff, S.; Lowenstine, L.J.; Marin, R., 3rd; Miller, P.E.; McLellan, W.A.; Moeller, P.D.; Powell, C.L.; Rowles, T.; Silvagni, P.; Silver, M.; Spraker, T.; Trainer, V.; van Dolah, F.M. Mortality of sea lions along the central California coast linked to a toxic diatom bloom. Nature 2000, 403, 80-84.

145. Brodie, E.C.; Gulland, F.M.D.; Greig, D.J.; Hunter, M.; Jaakola, J.; Leger, J.S.; Leighfield, T. A.; van Dolah, F.M. Domoic acid causes reproductive failure in California sea lions (Zalophus californianus). Mar. Mam. Sci. 2006, 22, 700-707.

146. Goldstein, T.; Zabka, T.S.; Delong, R.L.; Wheeler, E.A.; Ylitalo, G.; Bargu, S.; Silver, M.; Leighfield, T.; van Dolah, F.; Langlois, G.; Sidor, I.; Dunn, J.L.; Gulland, F.M. The role of domoic acid in abortion and premature parturition of California sea lions (Zalophus californianus) on San Miguel Island, California. J Wildl. Dis. 2009, 45, 91-108.

147. Lefebvre, K.A.; Powell, C.L.; Busman, M.; Doucette, G.J.; Moeller, P.D.R.; Silver, J.B.; Miller, P.E.; Hughes, M.P.; Singaram, S.; Silver, M.W.; Tjeerdema, R.S. Detection of domoic acid in northern anchovies and California sea lions associated with an unusual mortality event. Nat. Tox. 1999, 7, 85-92.

148. Lefebvre, K.A.; Dovel, S.L.; Silver, M.W. Tissue distribution and neurotoxic effects of domoic acid in a prominent vector species, the northern anchovy Engraulis mordax. Mar. Biol. 2001, 138, 693-700.

149. Kvitek, R.; Goldberg, J.D.; Smith, G.J.; Doucette, G.J.; Silver, M.W. Domoic acid contamination within eight representative species from the benthic food web of Monterey Bay, California, USA. Mar. Ecol. Prog. Series 2008, 367, 35-47.

150. Ramsdell, J.S. The molecular and integrative basis to domoic acid toxicity. In Phycotoxins: Chemisty and Biochemistry; Botana, L., Ed.; Blackwell Publishing: Ames, IO, USA, 2007; pp. 223-250.

151. Maucher, J.M.; Ramsdell, J.S. Maternal-fetal transfer of domoic acid in rats at two gestational time points. Environ. Health Perspect. 2007, 115, 1743-1746. 
152. Liu, H.; Kelly, M.S.; Campbell, D.A.; Dong, S.L.; Zhu, J.X.; Wang, S.F. Exposure to domoic acid affects larval development of king scallop Pecten maximus (Linnaeus, 1758). Aquat. Toxicol. 2007, 81, 152-158.

153. Pesando, D.; Huitorel, P.; Dolcini, V.; Amade, P.; Girard, J.P. Caulerpenyne interferes with microtubule-dependent events during the first mitotic cycle of sea urchin eggs. Eur. J. Cell Biol. 1998, 77, 19-26.

154. O'Brien, E.T.; Asai, D.J.; Jacobs, R.S.; Wilson, L. Selective inhibition of cytokinesis in sea urchin embryos by low concentrations of stypoldione, a marine natural product that reacts with sulfhydryl groups. Mol. Pharmacol. 1989, 35, 635-642.

155. Premakumara, G.A.; Ratnasooriya, W.D.; Tillekeratne, L.M.; Amarasekare, A.S.; Atta-UrRahman. Human sperm motility stimulating activity of a sulfono glycolipid isolated from Sri Lankan marine red alga Gelidiella acerosa. Asian J. Androl. 2001, 3, 27-31.

156. Ratnasooriya, W.D.; Premakumara, G.A.; Tillekeratne, L.M. Post-coital contraceptive activity of crude extracts of Sri Lankan marine red algae. Contraception 1994, 50, 291-299.

157. Williamson, J.E.; Carson, D.G.; de Nys, R.; Steinberg, P.D. Demographic consequences of an ontogenetic shift by a sea urchin in response to host plant chemistry. Ecology 2004, 85, 13551371.

158. Ohta, E.; Okada, H.; Ohta, S.; Kobayashi, M.; Kitagawa, I.; Horiike, S.; Takahashi, T.; Hosoya, H.; Yamamoto, K.; Ikegami, S. Malformation of immature starfish oocytes by theonellapeptolide Ie, a tridecapeptide lactone from a marine sponge Petrosia species, through disturbance of cortical F-actin distribution. Biosci. Biotechnol. Biochem. 2003, 67, 1908-1915.

159. Liu, H.; Namikoshi, M.; Meguro, S.; Nagai, H.; Kobayashi, H.; Yao, X. Isolation and characterization of polybrominated diphenyl ethers as inhibitors of microtubule assembly from the marine sponge Phyllospongia dendyi collected at Palau. J. Nat. Prod. 2004, 67, 472-474.

160. Liu, H.; Namikoshi, M.; Akano, K.; Kobayashi, H.; Nagai, H.; Yao, X. Seven new meroditerpenoids, from the marine sponge Strongylophora strongylata, that inhibited the maturation of starfish oocytes. J. Asian Nat. Prod. Res. 2005, 7, 661-670.

161. Bubb, M.R.; Senderowicz, A.M.; Sausville, E.A.; Duncan, K.L.; Korn, E.D. Jasplakinolide, a cytotoxic natural product, induces actin polymerization and competitively inhibits the binding of phalloidin to F-actin. J. Biol. Chem. 1994, 269, 14869-14871.

162. Terada, Y.; Simerly, C.; Schatten, G. Microfilament stabilization by jasplakinolide arrests oocyte maturation, cortical granule exocytosis, sperm incorporation cone resorption, and cell-cycle progression, but not DNA replication, during fertilization in mice. Mol. Reprod. Dev. 2000, 56, 89-98.

163. Schatten, G.; Schatten, H.; Spector, I.; Cline, C.; Paweletz, N.; Simerly, C.; Petzelt, C. Latrunculin inhibits the microfilament-mediated processes during fertilization, cleavage and early development in sea urchins and mice. Exp. Cell Res. 1986, 166, 191-208.

164. Spector, I.; Shochet, N.R.; Blasberger, D.; Kashman, Y. Latrunculins--novel marine macrolides that disrupt microfilament organization and affect cell growth: I. Comparison with cytochalasin D. Cell Motil. Cytoskeleton 1989, 13, 127-144. 
165. Ohta, E.; Uy, M.M.; Ohta, S.; Yanai, M.; Hirata, T.; Ikegami, S. Anti-fertilization activity of a spirocyclic sesquiterpene isocyanide isolated from the marine sponge Geodia exigua and related compounds. Biosci. Biotechnol. Biochem. 2008, 72, 1764-1771.

166. Kobayashi M, Kanzaki K, Katayama S, Ohashi K, Okada H, Ikegami S, Kitagawa I. Marine natural products. XXXIII. Theonellapeptolide IId, a new tridecapeptide lactone from the Okinawan marine sponge Theonella swinhoei. Chem. Pharm. Bull. (Tokyo) 1994, 42, 1410-1415.

167. Ikegami, S.; Kobayashi, H.; Myotoishi, Y.; Ohta, S.; Kato, K.H. Selective inhibition of exoplasmic membrane fusion in echinoderm gametes with jaspisin, a novel antihatching substance isolated from a marine sponge. J. Biol. Chem. 1994, 269, 23262-23267.

168. Ohta, S.; Kobayashi, H.; Ikegami, S. Jaspisin: A novel styryl sulfate from the marine sponge, Jaspis species. Biosci. Biotechnol. Biochem. 1994, 58, 1752-1753.

169. Kato, K.H.; Takemoto, K.; Kato, E.; Miyazaki, K.; Kobayashi, H.; Ikegami, S. Inhibition of sea urchin fertilization by jaspisin, a specific inhibitor of matrix metalloendoproteinase. Dev. Growth Differ. 1998, 40, 221-230.

170. Uno, M.; Ohta, S.; Ohta, E.; Ikegami, S. Callyspongins A and B: Novel polyacetylene sulfates from the marine sponge Callyspongia truncata that inhibit fertilization of starfish gametes. $J$. Nat. Prod. 1996, 59, 1146-1148.

171. Kobayashi, M.; Shimizu, N.; Kitagawa, I.; Kyogoku, Y.; Harada, N.; Uda, H. Absolute stereostructures of halenaquinol and halenaquinol sulfate, pentacyclic hydroquinones from the Okinawan marine sponge Xestospongia sapra, as determined by theoretical calculation of CD spectra. Tetrahedron Lett. 1985, 26, 3833-3836.

172. Ikegami, S.; Kajiyama, N.; Ozaki, Y.; Myotoishi, Y.; Miyashiro, S.; Takayama, S.; Kobayashi, M.; Kitagawa, I. Selective inhibition of membrane fusion events in echinoderm gametes and embryos by halenaquinol sulfate. FEBS Lett. 1992, 302, 284-286.

173. Ishihara, H. Calyculin A and okadaic acid: Inhibitors of protein phosphatase activity. Biochem. Biophys. Res. Commun. 1989, 159, 871-877.

174. Smith, G.D.; Sadhu, A.; Wolf, D.P. Transient exposure of rhesus macaque oocytes to calyculinA and okadaic acid stimulates germinal vesicle breakdown permitting subsequent development and fertilization. Biol. Reprod. 1998, 58, 880-886.

175. Agius, L.; Jaccarini, V.; Ballantine, J.A.; Ferrito, V.; Pelter, A.; Psaila, A.F.; Zammit, V.A. Photodynamic action of bonellin, an integumentary chlorin of Bonellia viridis, Rolando (Echiura, Bonelliidae). Comp. Biochem. Physiol. B 1979, 63, 109-117.

176. Pelter, A.; Ballantine, J.A..; Ferrito, V.; Jaccarino, V.; Psaila, A.F.; Schembri, P.J. Bonellin, a most unusual chlorin. J. Chem. Soc. Chem. Comm. 1976, 23, 999-1000.

177. Cariello, L.; De Nicola Giudici, M.; Tosti, E.; Zanetti, L. On the mechanism of action of bonellin on the sea urchin egg. Gamete Res. 1982, 5, 161-166.

178. De Nicola Giudici, M. Inhibition of motility by bonellin. II. Spermatozoa and embryos of sea urchin. Acta Embryol. Morphol. Exp. 1982, 3, 97-106.

179. Lakshmi, V.; Saxena, A.; Mishra, S.K.; Raghubir, R.; Srivastava, M.N.; Jain, R.K.; Maikhuri, J.P.; Gupta, G. Spermicidal activity of bivittoside D from Bohadschia vitiensis. Arch. Med. Res. 2008, 39, 631-638. 
180. Simon-Levert, A.; Arrault, A.; Bontemps-Subielos, N.; Canal, C.; Banaigs, B. Meroterpenes from the ascidian Aplidium aff. densum. J. Nat. Prod. 2005, 68, 1412-1415.

181. Simon-Levert, A.; Aze, A.; Bontemps-Subielos, N.; Banaigs, B.; Genevière, A.M. Antimitotic activity of methoxyconidiol, a meroterpene isolated from an ascidian. Chem. Biol. Interact. 2007, 168, 106-116.

182. Sipkema, D.; Franssen, M.C.; Osinga, R.; Tramper, J.; Wijffels, R.H. Marine sponges as pharmacy. Mar. Biotechnol. 2005, 7, 142-162.

183. MarinLit. A marine literature database maintained by the Marine Chemistry Group. University of Canterbury: Christchurch, New Zealand, 1999.

184. Faulkner, D.J. Marine natural products. Nat. Prod. Rep. 2000, 17, 7-55.

185. Faulkner, D.J. Marine natural products. Nat. Prod. Rep. 2001, 18, 1-49.

186. Faulkner, D.J. Marine natural products. Nat. Prod. Rep. 2002, 19, 1-48.

187. Wijffels, R.H. Potential of sponges and microalgae for marine biotechnology. Trends Biotechnol. 2007, 26, 26-31.

188. Mayer, A.M.S.; Gustafson K.R. Marine Pharmacology in 2005-6: Antitumor and Cytotoxic Compounds. Eur. J. Cancer 2008, 44, 2357-2387.

189. Glaser, K.B.; Mayer, A.M.S. A Renaissance in Marine Pharmacology: From Preclinical Curiosity to Clinical Reality. Biochem. Pharmacol. 2009, 78, 440-448.

190. Mayer, A.M.S.; Rodriguez, A.D.; Berlinck, R.; Hamann, M.T. Marine pharmacology in 2005-6: Marine Compounds with Antibacterial, Anticoagulant, Antifungal, Anthelmitic, Antiinflammatory, Antiprotozoal, and Antiviral Activities; affecting the Cardiovascular, Endocrine, Immune and Nervous Systems and other Miscellaneous Mechanisms of Action. Biochem. Biophys. Acta 2009, 1790, 283-308.

191. Kitagawa, I.; Kobayashi, M.; Kitanaka, K.; Kido, M.; Kyogoku, Y. Marine natural products, XII: On the chemical constituents of the Okinawan marine sponge Hymeniacidon aldis. Chem. Pharm. Bull. 1983, 31, 2321-2328.

192. Fedoreev, S.A.; Prokof'eva, N.G.; Denisenko, V.A.; Rebachuk, N.M. Cytotoxic activity of aaptamines from suberitid marine sponges. Pharm. Chem. J. 1989, 22, 615-618.

193. Willis, R.H.; De Vries, D.J. BRS1, a C30 bis-amino, bis-hydroxy polyunsaturated lipid from an Australian calcareous sponge that inhibits protein kinase C. Toxicon. 1997, 35, 1125-1129.

194. Jares-Erijman, E.A.; Sakai, R.; Rinehart, K.L. Crambescidins: New antiviral and cytotoxic compounds from the sponge Crambe crambe. J. Ore Chem. 1991, 56, 5712-5715.

195. Berlinck, R.G.S.; Braekman, J.C.; Daloze, D.; Bruno, I.; Riccio, R.; Ferri, S.; Spampinato, S.; Speroni, E. Polycyclic guanidine alkaloids from the marine sponge Crambe crambe and $\mathrm{Ca}^{++}$ channel blocker activity of crambescidin 816. J. Nat. Prod. 1993, 56, 1007-1015.

196. Wang, D.Z. Neurotoxins from marine dinoflagellates: A brief review. Mar. Drugs 2008, 6, 34971.

197. Kem, W.R. Sea anemone toxins: Structure and action. In The Biology of Nematocysts; Hessinger, D.A., Lenhoff, H.M., Eds.; Academic Press: New York, NY, USA, 1988; pp. 375-405.

198. Kem, W.R.; Pennington, M.W.; Dunn, B.M. Sea anemone polypeptide toxins affecting sodium channels. Initial structure-activity investigations. In Marine Toxins. Origin, Structure and 
Molecular Pharmacology; Hall, S., Stricharz, G., Eds.; American Chemical Society: Washington, USA, 1990; pp. 279-289.

199. Norton, T.R. Cardiotonic polypeptides from Anthopleura xanthogrammica (Brandt) and A. elegantissima (Brandt). Fed. Proc. 1981, 40, 21-25.

200. Honma, T; Shiomi, K. Peptide toxins in sea anemones: Structural and functional aspects. Mar. Biotechnol. 2006, 8, 1-10.

201. Llewellyn, L.E. Sodium channel inhibiting marine toxins. Prog. Mol. Subcell. Biol. 2009, 46, 67-97.

202. Castañeda, O.; Sotolongo, V.; Amor, A.M.; Stöklin, R.; Anderson, A.J.; Harvey, A.L.; Engström, A.; Wernstedt, C.; Karlsson, E. Characterization of a potassium channel toxin from the Caribbean sea anemone Stichodactyla helianthus. Toxicon. 1995, 33, 603-613.

203. Schweitz, H.; Bruhn, T.; Guillemare, E.; Moinier, D.; Lancelin, J-M.; Béress, L.; Lazdunski, M. Kalicludines and kaliseptine. Two different classes of sea anemone toxins for voltage-sensitive K+ channels. J. Biol. Chem. 1995, 270, 25121-25126.

204. Cotton, J.; Crest, M.; Bouet, F.; Alessandri, N.; Gola, M.; Forest, E.; Karlsson, E.; Castañeda, O.; Harvey, A.L.; Vita, C.; Ménez, A. A potassium-channel toxin from the sea anemone Bunodosoma granulifera, an inhibitor for Kv1 channels. Revision of the amino acid sequence, disulfide-bridge assignment, chemical synthesis, and biological activity. Eur. J. Biochem. 1997, 244, 192-202.

205. Gendeh, G.S.; Young, L.C.; de Medeiros, L.C.; Jeyaseelan, K.; Harvey, A.L.; Chung, M.C.M. A new potassium channel toxin from the sea anemone Heteractis magnifica: Isolation, cDNA cloning, and functional expression. Biochemistry 1997, 36, 11461-11471.

206. Minagawa, S.; Ishida, M.; Nagashima, Y.; Shiomi, K. Primary structure of a potassium channel toxin from the sea anemone Actinia equina. FEBS Lett. 1998, 427, 149-151.

207. De Smet, P.; Parys, J.B.; Callewaert, G.; Weidema, A.F.; Hill, E.; De Smedt, H.; Erneux, C.; Sorrentino, V.; Missiaen, L. Xestospongin $\mathrm{C}$ is an equally potent inhibitor of the inositol 1,4,5triphosphate receptor and the endoplasmic-reticulum $\mathrm{Ca}^{2+}$ pumps. Cell Calcium 1999, 26, 9-13.

208. Hirata, Y.; Uemura, D. Halichondrins - antitumor polyether macrolides from a marine sponge. Pure Appl. Chem. 1986, 58, 701-710.

209. Bai, R.L.; Paull, K.D.; Herald, C.L.; Malspeis, L.; Pettit, G.R.; Hamel, E. Halichondrin B and homohalichondrin $\mathrm{B}$, marine natural products binding in the vinca domain of tubulin: Discovery of tubulin-based mechanism of action by analysis of differential cytotoxicity data. J. Biol. Chem. 1991, 266, 15882-15889.

210. Bai, R.; Cichacz, Z.A.; Herald, C.L.; Pettit, G.R.; Hamel, E. Spongistatin 1, a highly cytotoxic, sponge-derived, marine natural product that inhibits mitosis, microtubule assembly, and the binding of vinblastine to tubulin. Mol. Pharmacol. 1993, 44, 757-766.

211. Koiso, Y.; Morita, K.; Kobayashi, M.; Wang, W.; Ohyabu, N.; Iwasaki, S. Effects of arenastatin A and its synthetic analogs on microtubule assembly. Chemico-Biol. Interact. 1996, 102, 183191.

212. Ter Haar, E.; Kowalski, R.J.; Hamel, E.; Lin, C.M.; Longley, R.E.; Gunasekera, S.P.; Rosenkranz, H.S.; Day, B.W.Discodermolide, a cytotoxic marine agent that stabilizes microtubules more potently than taxol. Biochemistry 1996, 35, 243-250. 
213. Anderson, H.J.; Coleman, J.E.; Andersen, R.J.; Roberge, M. Cytotoxic peptides hemiasterlin, hemiasterlin A and hemiasterlin B induce mitotic arrest and abnormal spindle formation. Cancer Chemother. Pharmacol. 1997, 39, 223-226.

214. Mooberry, S.L.; Tien, G.; Hernandez, A.H.; Plubrukarn, A.; Davidson, B.S. Laulimalide and isolaulimalide, new paclitaxel-like microtubule-stabilizing agents. Cancer Res. 1999, 59, 653660.

215. Hood, K.A.; West, L.M.; Rouwé, B.; Northocote, P.T.; Berridge, M.V.; Wakefield, S.J.; Miller, J.H. Peloruside A, a novel antimitotic agent with paclitaxel-like microtabule-stabilizing activity. Cancer Res. 2002, 62, 3356-3360.

216. Isbrucker, R.A.; Cummins, J.; Pomponi, S.A.; Longley, R.E.; Wright, A.E. Tubulin polymerizing activity of dictyostatin 1, a polyketide of marine sponge origin. Biochem. Pharmacol. 2003, 66, 75-82.

217. Kashman, Y.; Groweiss, A.; Shmueli, U. Latruncutin, a new 2-thiazolidinone macrolide from the marine sponge Latrunculia magnifica. Tetrahedron Lett. 1980, 21, 3629-3632.

218. Coue, M.; Brenner, S.L.; Spector, I.; Korn, E.D. Inhibition of actin polymerization by latrunculin A. FEBS Lett. 1987, 213, 316-318.

219. Fusetani, N.; Yasumuro, K.; Matsunaga, S.; Hashimoto, K. Mycalolides A-C, hybrid macrolides of ulapualides and halichondramide, from a sponge of the genus Mycale. Tetrahedron Lett. 1989, 30, 2809-2812.

220. Saito, S.; Watabe, S.; Ozaki, H.; Fusetani, N.; Karaki, H. Mycalolide, a novel actin depolymerizing agent. J. Biol. Chem. 1994, 269, 29710-29714.

221. Bubb, M.R.; Spector, I.; Bershadsky, A.D.; Korn, E.D. Swinholide A is a microfilament disrupting marine toxin that stabilizes actin dimers and severs actin filaments. J. Biol. Chem. 1995, 270, 3463-3466.

222. Anderluh, G.; Macek, P. Cytolytic peptide and protein toxins from sea anemones (Anthozoa: Actiniaria). Toxicon. 2002, 40, 111-124.

223. Crnigoj Kristan, K.; Viero, G.; Dalla Serra, M.; Maček, P.; Anderluh, G. Molecular mechanism of pore formation by actinoporins. Toxicon. 2009, epub ahead of print

224. Amador, M.L.; Jimeno, J.; Paz-Ares, L.; Cortes-Funes, H.; Hidalgo, M. Progress in the development and acquisition of anticancer agents from marine sources. Ann. Oncol. 2003, 14, 1607-1615.

225. D'Incalci, M.; Simone, M.; Tavecchio, M.; Damia, G.; Garbi, A.; Erba, E. New drugs from the sea. J. Chemother. 2004, 16, 86-89.

226. Russo, G.L.; Ciarcia, G.; Presidente, E.; Siciliano, R.A.; Tosti, E. Cytotoxic and apoptogenic activity of a methanolic extract from the marine invertebrate Ciona intestinalis on malignant cell lines. Med. Chem. 2008, 4, 106-109.

(C) 2009 by the authors; licensee Molecular Diversity Preservation International, Basel, Switzerland. This article is an open-access article distributed under the terms and conditions of the Creative Commons Attribution license (http://creativecommons.org/licenses/by/3.0/). 